\title{
Financial Services
}

\section{An analysis of the decision in Kleinwort Benson by Alastair Hudson}

This note should be of interest to those considering over-the-counter derivatives and those considering the impact on the law of restitution and of trusts of the recent litany of swaps cases.

\section{PASSING ON DEFENCE}

The Court of Appeal in Kleinwort Benson v Birmingham City Council [1996] 4 All ER 733 considered the availability of the defence of passing on. The plaintiff bank had entered into an interest rate swap agreement with the defendant local authority. In the wake of the House of Lords' decision in Hazell $v$ Hammersmith \& Fulham LBC [1992] 2 AC 1, it transpired that the agreement was void, being ultra vires the local authority. The agreement had provided that the parties owed amounts of money to one another calculated by reference to a notional amount of money. Usually, one payment is a floating rate of interest which has been swapped for the other payment, which is a fixed rate of interest (in many of these swaps cases, a loan was made as part of the agreement and it was by reference to the amount of that loan that payments were calculated).

The bank contended that the defence of passing on should be available to it, on the basis that it had entered into further interest rate swap agreements with third parties, to hedge its risk under the agreement with the local authority. It was this hedge that was said to constitute the passing on. The reasoning behind this was that the amount owed to the third party would be the inverse to that owed to or received from the local authority: the value of the hedge would be calculated to move in an opposite and roughly equal way to the value of the main contract.

The Court of Appeal held that the hedging agreement was not a part of the main agreement with the local authority, therefore amounts paid under it would not attract the defence of passing on. The decision of the Court of Appeal in Kleinwort Benson is predicated on the difficult proposition advanced by
Hobhouse J that, when reciprocal payments are made under an interest rate swap:

'the later payment is treated as, pro tanto, repayment of the earlier sum paid by the other party' ([1994] 4 All ER 890 at p. 929 per Hobhouse J and affirmed at [1996] 4 All ER 733 at p. 738 per Evans LJ).

\section{REPAYMENT ANALYSIS}

There are two practical issues to confront here and one theoretical one. The first practical problem is that there are not usually two payments made: payment netting applies so that only one amount of money is transferred on a net basis. There is therefore a difficulty in saying that a single payment is a repayment of an amount which was never paid.

The second practical problem is whether the reference to a repayment made by Hobhouse J means a payment which has already been made. There is insufficient evidence available in the judgments to know whether or not payments were made reciprocally, and not on a net basis, such that the repayment hypothesis could have some grounding in fact. It seems unlikely that this was the case - it would be very exceptional for payment netting not to be used in the mature derivatives markets. Even when dealing with illiquid assets, most derivatives contracts contain some formula by which a net amount can be calculated. The appointment of a calculation agent between the parties is done with exactly this in mind.

The theoretical question is then: how should an interest rate swap be analysed? At one level there is a single contract under which the parties agree to make reciprocal payments which are reduced to a single net amount and that net amount is paid across (the single executory contract analysis). However, many models for calculating the appropriate pricing structure of an interest rate swap will see that swap as a series of mutual debts to be made between the parties, all binding from the time of the creation of the agreement but to be considered as separately enforceable. Thus there is no single executory contract, but rather a series of executory contracts which may or may not be performed. In either event, the contract does not consider payments to be repayments of one another. Payments are amounts payable one way calculated after set-off of simultaneous, reciprocal obligations.

Alternatively the interest rate swap agreement can be read as being made up of a series of individual contracts all subject to a condition precedent. It is possible that the floating and fixed amounts would cancel out with the result that there was no amount to be paid that is, the obligation would lead to no payment being made. Due to the payment netting provision, the condition precedent analysis would say that there is only a 50:50 chance that one of the parties will have to make a payment in any event. Rather than payments being reciprocal, at least one party will not be required to make any payment on each reset date.

Therefore, the analysis based on repayment does not appear to operate on any basis of practical or theoretical fact. As a result, its utility as a fiction appears to be similarly limited. It does not reflect any of the risk management or pricingmotivated analyses that form the parties' contractual common intention.

\section{ANALYSING THE SWAP}

Many models for calculating the appropriate pricing structure of an interest rate swap will see that swap as a series of mutual debts to be made between the parties.

\section{NO SINGLE CONTRACT}

We know little about the hedge in Kleinwort Benson. However, what can be discussed is standard market practice. A financial institution will not hedge each transaction on a separate basis. This is unlikely even if the trade is particularly 
large or particularly intricate. Rather, hedging strategies on the institution's proprietary liability (that is, in legal terms, its own personal liabilities) are organised on the basis of the entire swap book. The institution considers the broad range of its exposure, sometimes by currency or by type of business, and then sets in place hedging arrangements to contain that exposure within acceptable limits. Thus hedging is fluid and generally not contract-specific.

For the Court of Appeal to seek a nexus between the agreement with the local authority and the hedging agreement with a third party would necessarily be a difficult task. Tracing any asset through such a mixture would be similarly complicated.

However, the proper analysis of an interest rate swap, based on the analysis set out above, might show that it is possibly not a single executory contract in any event. The courts are assuming that there is one single contract (because the point is not being taken before them) and therefore looking for a hedge that operates in the same manner. When the interest rate swap is seen to be what it is, an amalgam of debts which may or may not crystallise, the nexus between the hedge to the original interest rate swap agreement perhaps seems less opaque.

The better approach might be to assess whether the risk assumed by the bank is one which the bank sought to address through hedging arrangements which were not a requirement of the agreement any more than it was a requirement of the agrecment for the local authority to procure further risk management protection. The defence should only be available in those terms where the risk of passing on is within the common intention of the parties. In Kleinwort Benson the plaintiff's hedging strategy was the result of a unilateral

\section{ARTIFICIAL RESTRICTION}

The reasoning behind the Court of Appeal's decision appears to open as many issues as it resolves. By restricting itself to the classical discussion of passing on, the Court of Appeal is failing to appreciate the context of modern portfolio theory.

decision. The outcome of the Court of Appeal's decision appears to achieve a just result in those terms, but the reasoning behind it appears to open as many issues as it resolves. By restricting itself to the classical discussion of passing on, the Court of Appeal is failing to appreciate the context of modern portfolio theory.

\section{Alastair Hudson}

Queen Mary and Westfield College

\section{Land Law}

\section{The fight against gazumping}

\section{by Professor M P Thompson}

The new government, as part of its general reforming zeal, has decided to review the conveyancing procedures in England and Wales and, in particular, to seek to stamp out the practice of gazumping which, apparently, after the recent and prolonged slump in the property market, has returned to cast its shadow over the conveyancing scene. The practice is well known and almost universally frowned upon. In short, the vendor agrees, subject to contract, to sell

\section{PURCHASER'S COMPENSATION}

Changing the law to allow the purchaser compensation would certainly be seen by some as an improvement. A difficulty in the way of such a proposal is, however, its somewhat one-sided nature which may result in hardship to the vendor.

a house to the purchaser for, say, $£ 70,000$ and then subsequently refuses to exchange contracts unless the purchaser raises the price to $£ 75,000$ - usually because a higher offer has been made by another party. If the purchaser refuses to meet the new asking price, he or she is out of pocket as a result of incurring expenditure on search fees and a survey. The purchaser understandably feels aggrieved and considers that compensation should be available although the law at present offers no such remedy. The question which arises is whether some change in the law could usefully be made.

The enthusiasm to revisit the problem may be new but the difficulties in tackling it have been recognised for some considerable time. Probably the first occasion that gazumping came to public attention was the introduction, in 1971, by Kevin McNamara MP of the Abolition of Gazumping and Kindred Practices Bill. As is the usual fate of Private Members' bills, this did not reach the statute book; but the matter was referred to the Law Commission, who declined to recommend any legislative change. It is interesting to consider some of the proposals which were considered to determine what course of action, if any, might now be considered to be appropriate.

\section{POSSIBLE REMEDIES}

One option is to make the practice of gazumping a criminal offence. Apart from the very real problem of defining such an offence, there is a serious objection in principle. It is not generally a criminal offence to break a contract. This being the case, it is difficult to see any justification for the criminalisation of a refusal to enter a binding contract. The criminal law should, it is submitted, have no place in the present context.

An alternative to the imposition of criminal sanctions is to require the vendor to compensate the purchaser for expenditure which the latter incurs if the vendor seeks to back out of the deal. At present, the law will only award such compensation in unusual cases of precontractual expenditure and certainly only where the expenditure is that normally incurred in a conveyancing transaction - see Regalian Properties plc v London Docklands Development Corporation [1995] 1 All ER 1005. Changing the law to allow the purchaser compensation 